研 究

\title{
メカニカルミリング処理した共析鋼粉の固化成形
}

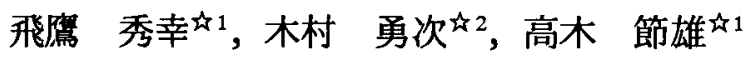 \\ 41 九州大学大学院工学研究科材料工学教室, 干 812-8581 福岡市東区箱崎 6-10-1. \\ 42 九州大学, [(現) 金属材料技術研究所, 干 305-0047 つくば市千現 1-2-1].
}

\section{Consolidation of Eutectoid Steel Powder with Mechanical Milling}

\author{
Hideyuki Hidaka ${ }^{\text {मे }}$, Yuuji Kimura ${ }^{\text {म2 }}$ and Setsuo Takaki ${ }^{\text {और }}$ \\ ${ }^{1}$ Materials Engineering Group, Graduate School of Engineering, Kyushu University, 6-10-1 Hakozaki Higashi-ku, Fukuoka 812-8581. \\ $4{ }^{2}$ Kyushu University, (Present Address: National Research Institute for Metals, 1-2-1 Sengen, Tsukuba 305-0047).
}

Received August 10, 1999

\begin{abstract}
SYNOPSIS
The mechanically milled $\mathrm{Fe}-0.8 \mathrm{mass} \% \mathrm{C}$ alloy powder (MM powder) was packed in stainiess steel tubes and hotrolled to consolidate powder to the bulk material with full density (MM bulk material), and the mechanism during consolidation of the MM powder was investigated by means of tensile testing at the consolidation temperature (973K) using the MM bulk material. The MM bulk material has micro-duplex structure which consists of ferrite and cementite grains of the size; $0.3 \mu \mathrm{m}$. The deformation stress of the $\mathrm{MM}$ bulk material is small as $80 \mathrm{MPa}$ at $973 \mathrm{~K}$, while high as $1700 \mathrm{MPa}$ at room temperature. Although the total elongation was not so large (about $100 \%$ ) under the condition of strain rate; $10^{-2} \sim 10^{-1} / \mathrm{s}^{-1}$ at $973 \mathrm{~K}$, the $\mathrm{m}$ value was estimated at 0.3 . Besides, it was confirmed that there were few dislocations within ferrite grains after tensile testing. These results demonstrate the fact that the MM bulk material deforms through the grain boundary sliding. Since the grain size in MM powder before consolidation (about $0.1 \mu \mathrm{m}$ ) is smaller than that in the MM bulk material (about $0.3 \mu \mathrm{m}$ ), MM powder is through to undergo superplastic deformation based on grain boundary sliding during the consolidation by hot-rolling.
\end{abstract}

KEY WORDS

mechanical milling, Fe-C alloy, consolidation, fine grain, superplasticity

\section{1 緒 言}

金属粉末を繰り返し圧接・鍛造するメカニカルミリンク (MM) 法は,ばく大な歪を金属に付与することが可能であり， 内部組織をナノサイスにまで微細化できる点に特幑がある。 しかし，MM 法で得られる素材は粉末であり，構造用材料と して利用するにはこれを固化成形し，バルク化するプロセス が必要となる.そこでわれわれは，一つの方法として MM処 理した粉末(MM粉末)をステンレスパイプに真空封入し熱間 圧延により固化成形する Mechanical Milling and Consolidation (MMC)プロセスを提案した.この方法はあくまでも熱間押出 加工を模擬したもので，長時間 MM 処理した Fe-0.8mass\% (\%)C 合金粉末は Hv1200 程度にまで加工硬化している ${ }^{1)} に も$ かかわらず,MMCプロセスによりほぼ真密度まで緻密化でき る.このような硬質の粉末が $700^{\circ} \mathrm{C}$ という比較的低温で十分 に固化成形できることは注目すべきである.このように優れ た緻密化特性が発現する理由として, MM粉末自体が固化成
形中に超塑性変形している可能性も示唆されたが，そのメカ ニスムはいまだ明らかにされていない. 本研究は, MM処理 した共析鋼粉の固化成形機構を明らかにすることを目的とし て, $\mathrm{Fe}-0.8 \% \mathrm{C}$ 合金粉末に関して，まず固化成形条件を調査し たのち, 得られたバルク材の高温変形挙動を検討した.

\section{2 実験方法}

原料粉末は, (フェライト $(\alpha \mathrm{Fe})+$ セメンタイト $(\theta))$ 二相組 織を有する $\mathrm{Fe}-0.8 \% \mathrm{C}$ 合金粉末である. MM 処理は，直径 $10 \mathrm{~mm}$ の鋼球 (300 個) と粉末を重量比が 20:1 になるように配 合して, SUS304製のポット (容積: 0.42L)に充填し, Arガス 雾囲気中で遊星型ボールミル装置を用いて最長 $360 \mathrm{ks}$ まで 行った。得られた $\mathrm{MM}$ 粉末は $45 \mu \mathrm{m}$ 以下 $(-325 \mathrm{mesh})$ に分級後, $873 \mathrm{~K}$ で脱ガス処理を行い, 直径 $16 \mathrm{~mm}$ (肉厚 $1 \mathrm{~mm}$ )のステンレ ス鋼製パイプに真空封入した.これを923〜1023Kで厚さ約 $1.2 \mathrm{~mm}$ まで熱間圧延することにより固化成形した(MMバルク 
材).また，比較材として，MM 処理を施していない粉末を 973Kで固化成形したバルク材(MMなし材)を同様な手順で作 製した.

走查電子顕微鏡 (SEM) 観察は，固化成形体の RD 面につい て行った。透過型電子顕微鏡 (TEM) 観察は，以下に示す手順 で作製した試料についてそれそれ行った。MM粉末はカーボ 二ル鉄粉と 1:1 の重量割合で混合した後，直径 $3 \mathrm{~mm}$ の穴開け 加エをしたステンレス鋼製の円柱容器 $(\phi 10 \mathrm{~mm} \times 10 \mathrm{~mm})$ に充

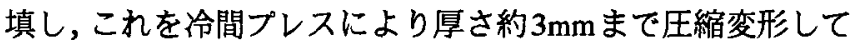
圧粉体を得た. 圧粉体および固化成形体は，放電加工とエメ リー研摩により $\phi 3 \mathrm{~mm} \times 0.1 \mathrm{~mm}$ のディスク状に加エした。こ れらのディスクは過塩素酸 $10 \%$ ・酢酸 $90 \%$ の電解液を用いた ッインジェット法で研磨して TEM 観察用の薄膜に仕上げた。

硬度は，マイクロビッカース硬度計を用いて測定し，荷重 $9.8 \mathrm{~N}$ で 10 点測定したのち上下 2 点を除いた 8 点の平均值とし た. 引張試験は, インストロン型試験機を用いて973Kにて Ar ガス雾囲気中で行い, 歪速度は $10^{-4} \sim 10 / \mathrm{s}^{-1}$ の間で変化させた。 なお，試験片は，固化成形体を $40 \times 10 \mathrm{~mm}$ の板状に切り出した 後に, 放電加エにより平行部を長さ $5 \mathrm{~mm} \times$ 幅 $3 \mathrm{~mm}$ に加エした。

\section{3 実験結果および考案}

\section{1 メカニルミリング好理した粉末の固化成形}

Fig.1 は, Fe-0.8\%C合金粉末の MM 処理にともなう X 線回 折パターンの変化を示す. MM 処理をほどこしていない試料 では $\alpha \mathrm{Fe}$ と $\mathrm{Fe}_{3} \mathrm{C}(\theta)$ からの鋭い回折ピークが観察されるが, $\theta$ の回折ピークはMM処理の経過にともなってしだいに消失す る傾向を示し，36ks以，上の MM粉末ではそれはほとんど消失 している.これは，MM処理によって $\theta$ が分解するためで， $108 \mathrm{ks}$ 以上MM処理した粉末では $\theta$ は完全に分解してしまうこ とを示差熱分析により確認している゙. また，MM処理に伴う

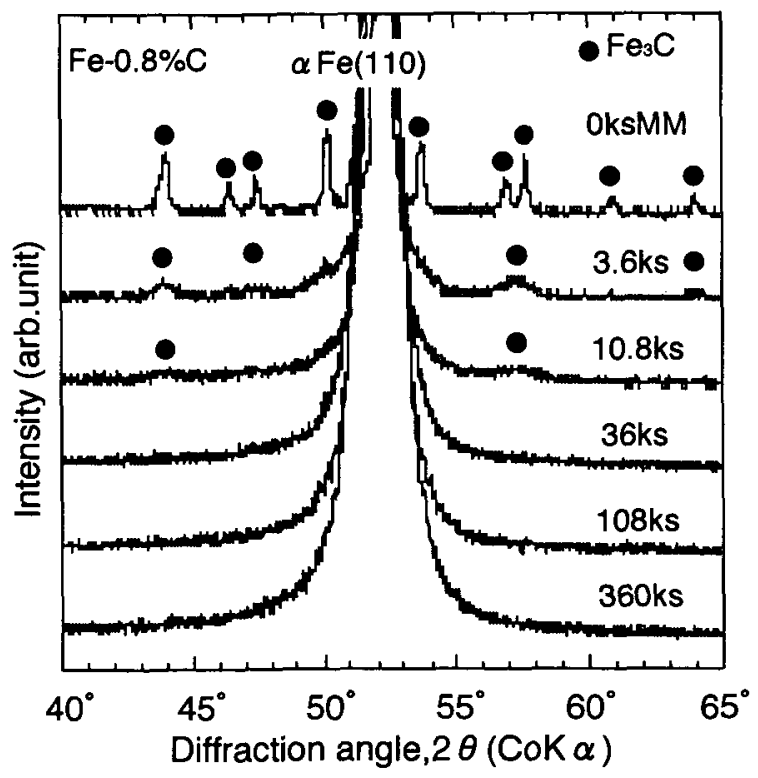

Fig.1 X-ray diffraction patterns of an $\mathrm{Fe}-0.8$ mass $\% \mathrm{C}$ alloy powder mechanically milled for various time. $\alpha \mathrm{Fe}$ 粒径と硬度の変化を調查した結果, $180 \mathrm{ks}$ 以上 $\mathrm{MM}$ 処理し た粉末では $\alpha \mathrm{Fe}$ 粒径は $10 \mathrm{~nm}$ 程度にまで微細化し，硬度は Hv1200 に達していた ${ }^{1)}$. 内部組織と硬度は 180ks の MM 処理 でほぼ定常状態に達することがわかったので，以降 MM処理 時間は180ks と決定した.内部組織は，Fig.2に示すように，粒 径か $10 \mathrm{~nm}$ の等軸 $\alpha \mathrm{Fe}$ 粒と， $\theta$ の分解によって生じた炭素が粒 界に偏析した粒界アモルファスから形成されることをすでに 確認している2．このような組織を有する MM 粉末を加熱す ると，約 650Kで $\theta$ の再析出が起こり，粒界アモルファスが消 失することもすでに確認している゙. Fig.3は，焼鈍に伴う $\alpha \mathrm{Fe}$

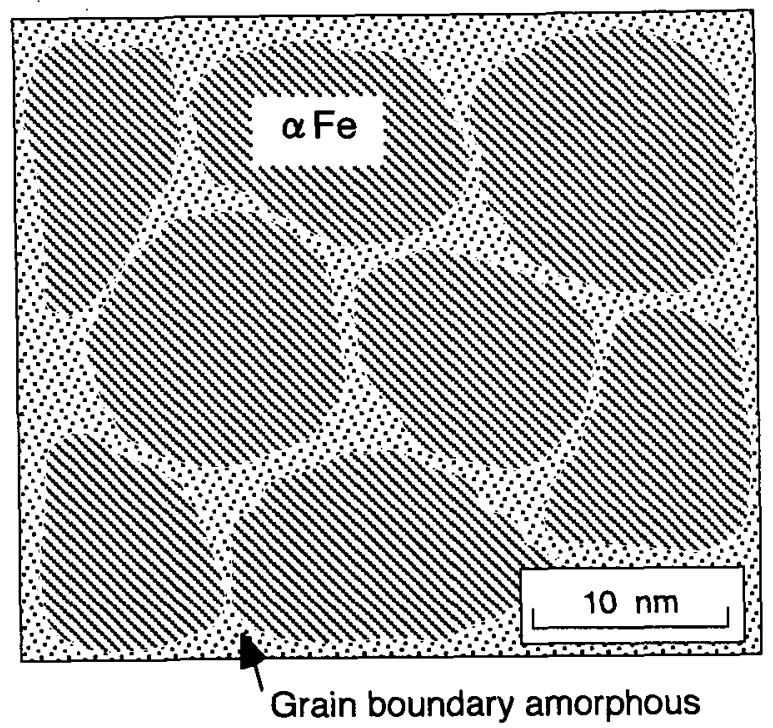

Fig.2 Schematic illustration showing the nanosized grain structure which has been formed in an $\mathrm{Fe}-0.8$ mass\% $\mathrm{C}$ alloy powder by mechanical milling treatment.

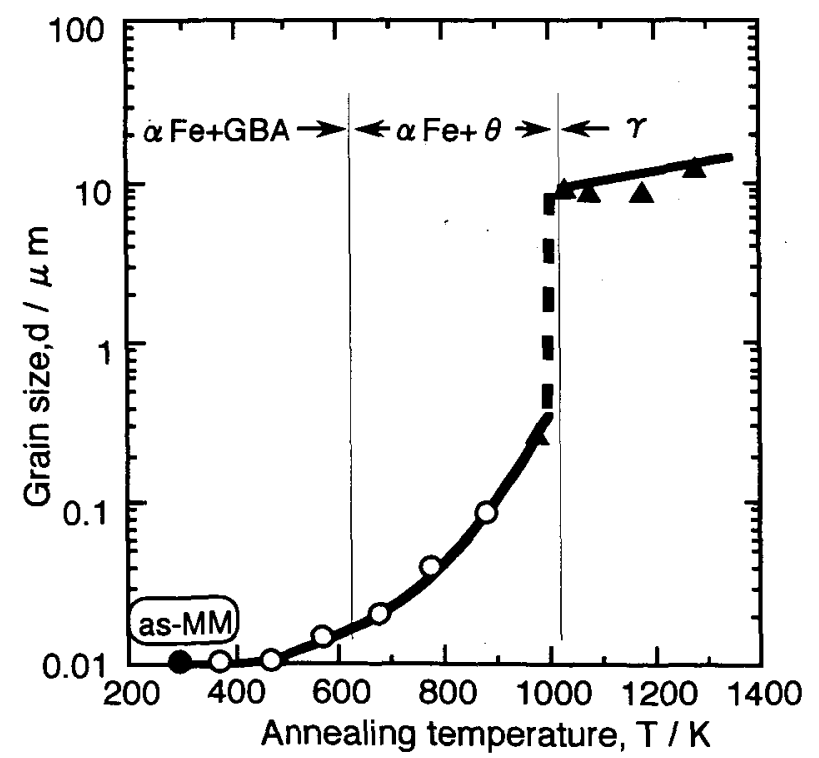

Fig.3 Change in the grain size of an Fe-0.8mass\%C alloy fabricated by mechanical milling, as a function of annealing temperature (powder; $\mathrm{O}$ or , bulk; $\mathbf{\Delta}$ ). GBA denotes Grain Boundary Amorphous layer with high concentration of carbon. 
粒径の変化を示す. $\alpha \mathrm{Fe}$ の粒成長挙動は $\theta$ の再析出が起こる温 度 $(650 \mathrm{~K})$ および $(\alpha \mathrm{Fe}+\theta) \rightarrow \gamma$ 逆変態の温度 $(1000 \mathrm{~K})$ を境に大 きく3つの領域に分けることができる. 650K以下の温度域で は $\alpha \mathrm{Fe}$ 粒径は数十 $\mathrm{nm}$ 以下に維持されている. 650K以上の温 度域では $\theta$ のオストワルド成長に起因して $\alpha \mathrm{Fe}$ 粒はしだいに 粗大化し, $1000 \mathrm{~K}$ 付近では $0.3 \mu \mathrm{m}$ 程度に達するが, この温度 域まで $0.3 \mu \mathrm{m}$ 程度の微細組織が維持される点は注目に值する. $(\alpha \mathrm{Fe}+\theta) \rightarrow \gamma$ 逆変態温度を越えると相変態をきっかけとした急 激な粒成長が起こり,結晶粒はいっきに $10 \mu \mathrm{m}$ 程度にまで粗大 化する.このことは超微細組織を有する鋼の場合, 相変態が 必ずしも結晶粒の微細化に貢献しないことを物語っており, むしろ変態誘起粒成長 (Transformation Assist Grain Growth: TAGG)という超細粒鋼に特有の問題が発現することを示して いる. Fig.4は, 種々の温度で固化成形したバルク材の固化成 形温度と硬度の関係を示す. 固化成形温度の上昇に伴いバル ク材の硬度はいったん上昇し, 973Kで極大值(約 Hv600)を示 したのち大幅に低下する. Fig.5は, 種々の温度で固化成形し たバルク材の SEM 組織を示す. 923Kで固化成形したバルク 材では粉末の焼結が十分でなく, (a)に示すようにある程度の 気孔が残存している.このことが923Kでの固化成形体の硬度 が低い理由であり, 成形体に割れが生じることもあった。こ れに対して, 973K 固化成形体(b)では, 硬度が最大となるだ けでなく, 密度も真密度に達していた. さらに固化成形温度 が高くなり 1000Kを越えると, (c)に示すように TAGGに起因 した粒成長が起こるようになるので, 固化成形温度は973Kに 決定した. TEM で観察した Fig.5(b)の試料の内部組織を Fig.6 に示す. 内部組織は, 結晶粒径 $0.3 \mu \mathrm{m}$ 程度の等軸状の $\alpha \mathrm{Fe}$ と $\theta$ からなる micro-duplex 組織であり, $\alpha \mathrm{Fe}$ と $\theta$ の体積比は理論 的には7:1となっていることが推察される.暗視野像に着目し

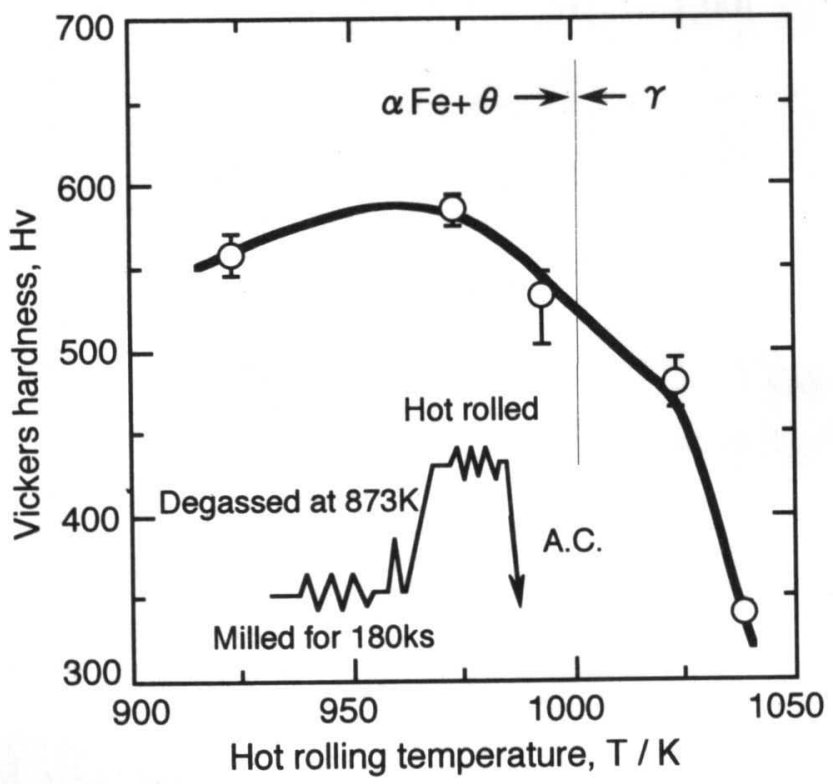

Fig.4 Relation between consolidation temperature and vickers hardness of the bulk materials fabricated from mechanically milled powder.
てみると $\alpha \mathrm{Fe}$ と $\theta$ のほとんどの結晶粒は大角粒界に囲まれて いることがわかる.また， $\alpha \mathrm{Fe}$ と $\theta$ 粒のほかに大きさ $10 \mathrm{~nm}$ 程 度の酸化物粒子が多数確認される.酸化物は原料粉末の作製 に用いた還元鉄粉末中に含まれていたものであり，その体積 率は約 $2 \mathrm{vol} . \%$ である. 酸化物は $\theta$ と同様に MM 処理により いったん基地中に分解し, その後の固化成形のための加熱過 程で再析出する場合があることもわかっている2． $\theta$ が存在し ない $\alpha \mathrm{Fe}$ 単相材では, 微細かつ均一に分散した酸化物粒子か $\alpha \mathrm{Fe}$ 粒の粒界をピンニングすることによって, 相変態直下の 温度域までサブミクロンの微細粒組織が維持されることも確

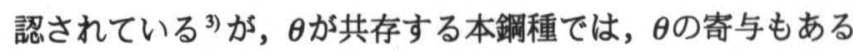
程度大きいように思われる.ここで注目すべき点は, 基地 $\alpha \mathrm{Fe}$ の粒内に転位がほとんど認められないことである. 本研究で
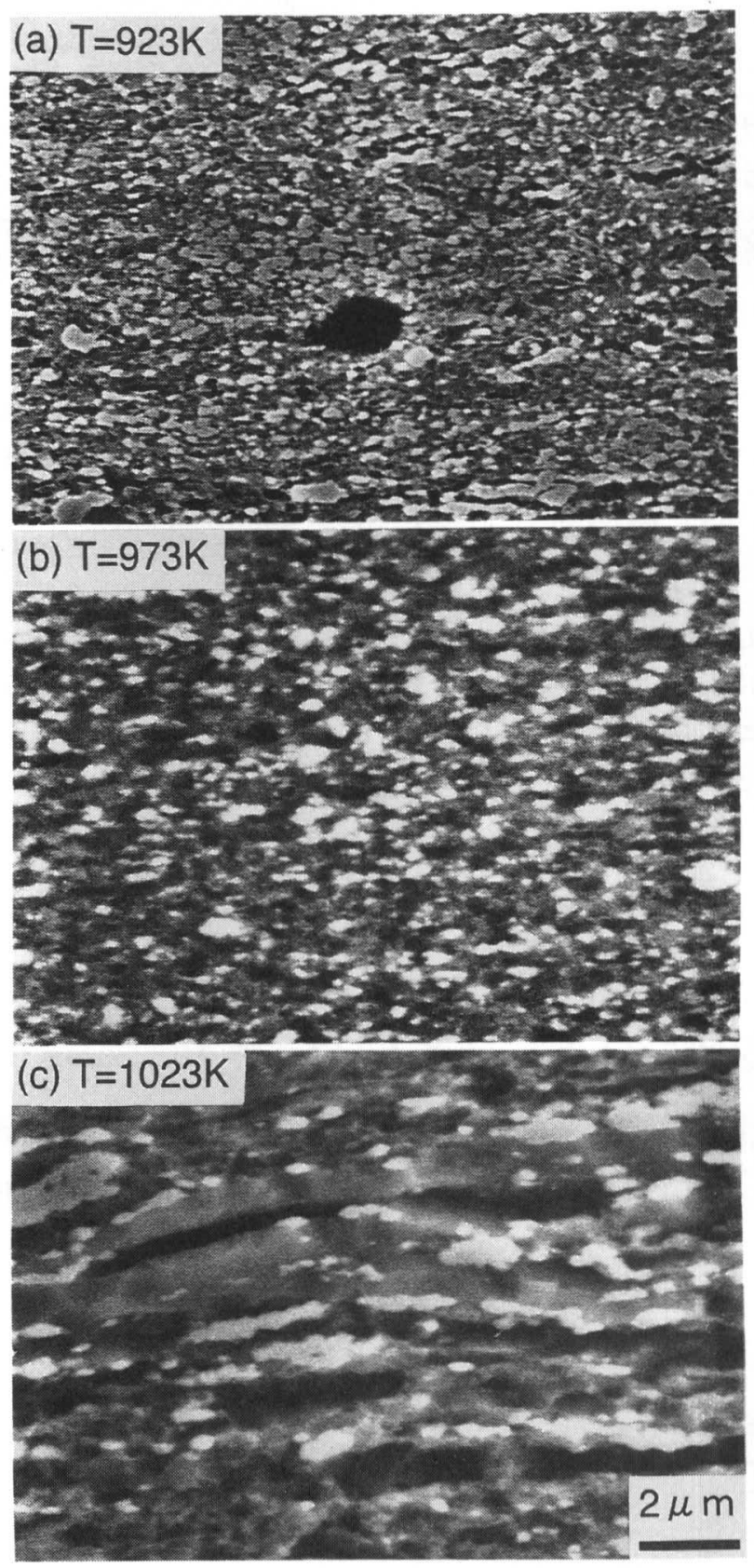

Fig.5 SEM images of Fe-0.8mass\%C bulk alloy shown in fig. 4 . 
は熱間圧延という比較的大きな歪速度で固化成形しているに もかかわらず，結晶粒は等軸状に保たれており，しかも粒内 には転位がほとんど観察されない，このことは，熱間圧延中 のMM粉末の変形が主に粒界すべりによってまかなわれてい ることを示唆している.

3.2 超微細 (フェライト+セメンタイト)二相組織を有する鋼 の高温変形挙動

MM 粉末の固化成形メカニスムを検討するうえで，粉末自 体の高温変形挙動を調查することは非常に困難なので, ここ

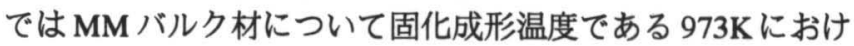

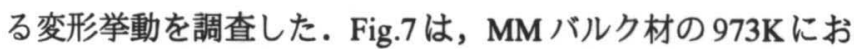
ける応力-歪曲線を示す. MM なし材と比較すると, MMバ ルク材では降伏応力が極端に低く，しかもある程度の伸びか 得られている. MM バルク材の変形に要する最大応力は $80 \mathrm{MPa}$ 程度であり, 室温での強度 (1700MPa) の $5 \%$ 以下にま で低下していることは注目すべきである. Fig.8は, MMバル ク材の $973 \mathrm{~K} に お け る$ 全伸びの初期歪速度依存性を示す. MM なし材では,ほとんど伸びが得られていないのに対して, MM バルク材では $10^{-2} \sim 10^{-1} / \mathrm{s}^{-1}$ という比較的大きな歪速度領域に おいて100\%以上の伸びが得られている.伸びの絶対值として はそれほど大きな值ではないが,このような歪速度の領域で 伸びの極大值が発現する現象は超塑性変形の特徵であり,

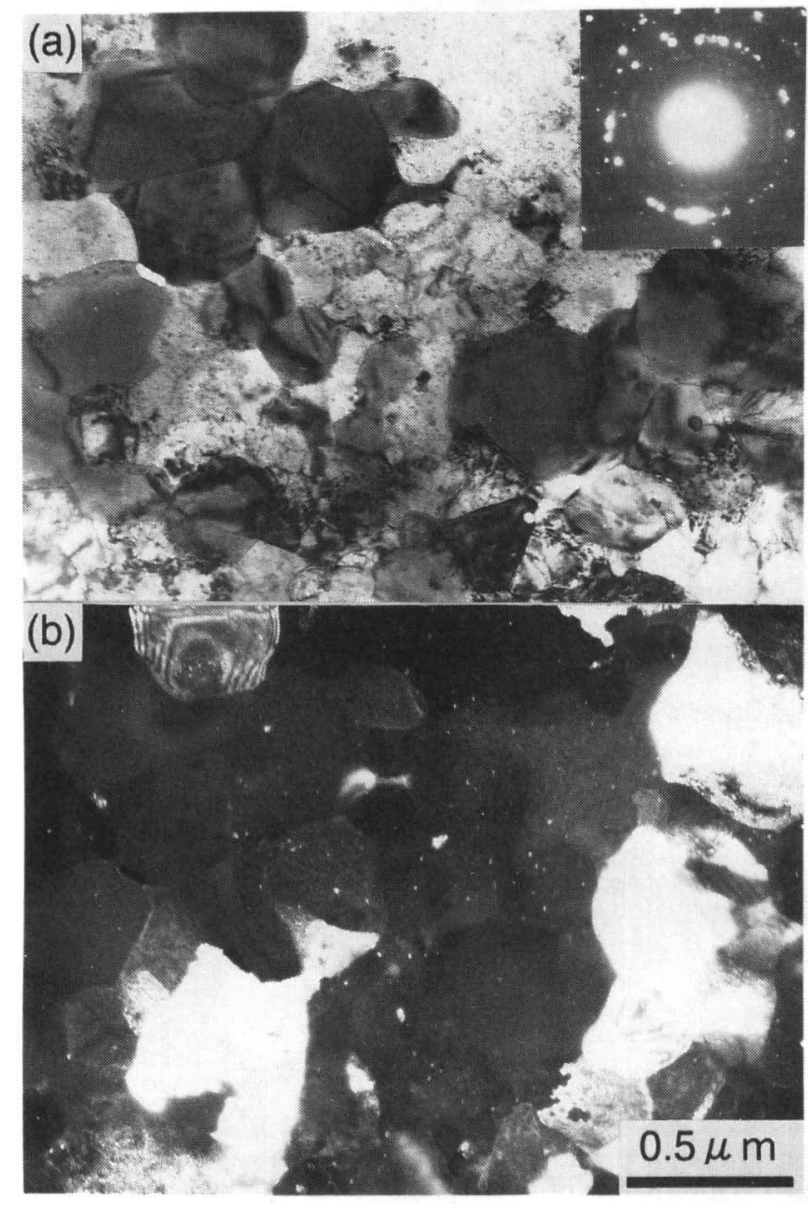

Fig.6 TEM images of Fig.5 (b); (a) Bright-field and (b) dark-field.
Fig.8の結果は，973Kでの変形中に粒界すべりが起こってい る可能性を示唆するものである.一般に, 材料の超塑性変形 発現の判断基準として歪速度感受性指数 ( $\mathrm{m}$ 值) が用いられ る. Fig.9は, 初期歪速度と変形応力の関係を示す.この曲線 の傾きが $\mathrm{m}$ 值を表し, MM バルク材では, $100 \%$ 以上の伸び を示す領域で $\mathrm{m}$ 值として約 0.3 の值が得られる. 多くの材料 で $\mathrm{m}$ 值と全伸びの関係が調查されており，この值が 0.3 を越 えると超塑性現象が発現すると言われている. Fig.10は， もっとも大きな伸びか得られた歪速度 $10^{-2} / \mathrm{s}^{-1}$ で引張試験を 行った試料の破面近傍のTEM組織を示す.粒内にはほとんど 転位は観察されず，また $\alpha \mathrm{Fe}$ 粒もほとんど粒成長せずに $0.3 \mu \mathrm{m}$ 程度の粒径で, 引張試験前とほほ同様な組織が保たれ ている.このことは, 上記の条件下における変形が粒界すべ りによってまかなわれている事実を示しており，内部により 微細な結晶粒 $($ 約 $0.1 \mu \mathrm{m})$ を有する MM粉末の固化成形時に粉 末自体の微細粒超塑性変形が起こっていることは間違いない。 本来, $\mathrm{Fe}-0.8 \% \mathrm{C}$ 組成の鋼は, 適切な加工熱処理を施してやる

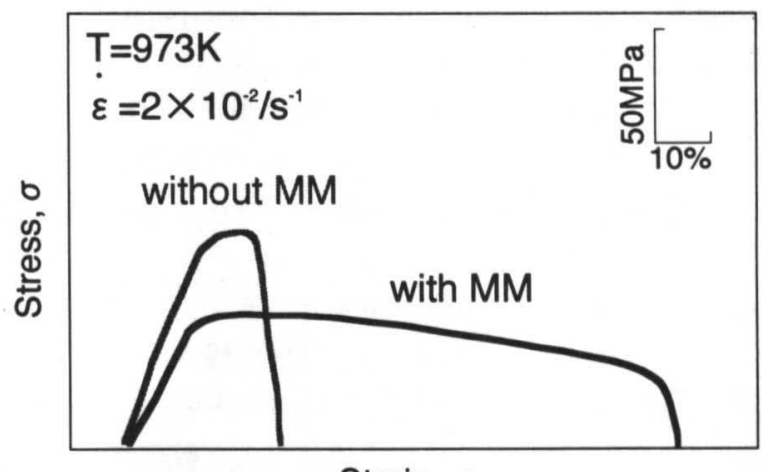

Strain, $\varepsilon$

Fig.7 Stress-Strain curves in Fe-0.8mass\%C bulk alloy fabricated from the steel powders with or without MM.

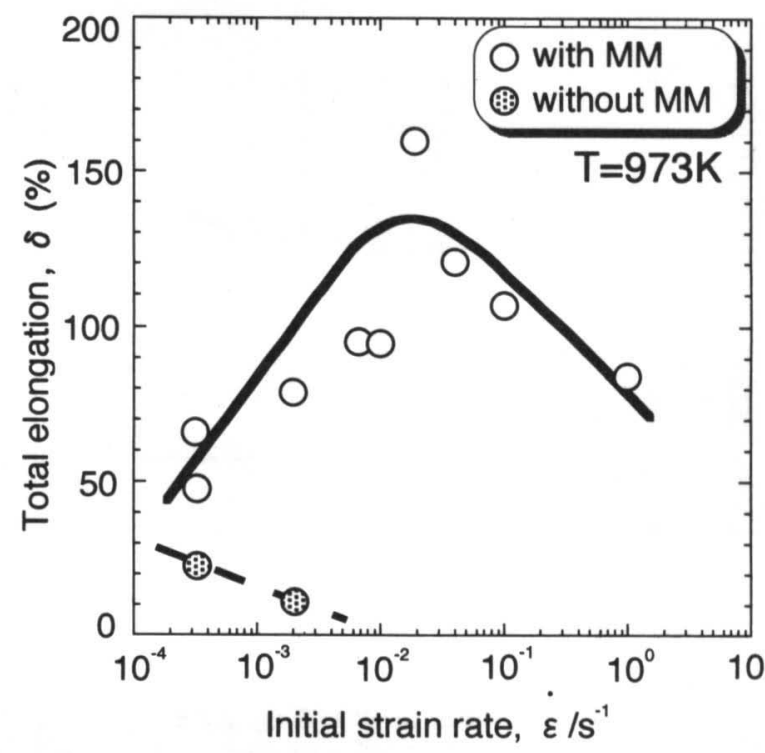

Fig.8 Relation between initial strain rate and total elongation in $\mathrm{Fe}-0.8$ mass \% C bulk alloy. 
と, $10^{-4} / \mathrm{s}^{-1}$ 程度の歪速度で約 $700 \%$ の超塑性伸びを示すこと も報告されている4). 本実験では同一組成の鋼種でありながら これほどの伸びは得られていない。これにはもちろん試験片 形状の影響も考えられるが, MMバルク材に存在する酸化物 粒子の影響が最も大きいと考えられる. 一般に超塑性材料の 破断は,ボイドの発生・連結によっておこるとされており,粒 界上に変形が困難な第二相が存在すると, 粒界すべりが起こ る過程で微粒子を起点としたマイクロボイドの発生が促進さ れるっ. 実際に本研究でも, 破断した試験片には破面近傍に多 くのボイドが観察された.このことは, 酸化物を母相結晶粒 のピン止め粒子として使用する場合, 粒子が結晶粒を微細に 保つ働きをする反面, ボイドの生成を促進して破断を早める という“諸刃の剣”に成り得る可能性を示唆している.

\section{4 ま と め}

（1）基地の $\alpha \mathrm{Fe}$ 粒は, 酸化物の粒界ピンニング効果によって $(\alpha \mathrm{Fe}+\theta) \rightarrow \gamma$ 逆変態が起こる約 $1000 \mathrm{~K}$ まで $0.3 \mu \mathrm{m}$ 程度の大 きさに保持され, それ以上の温度では変態誘起粒成長 (Transformation Assist Grain Growth; TAGG)により $10 \mu \mathrm{m}$ 程 度の大きさにまで急激に粒成長する。

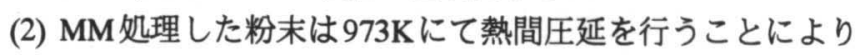
完全に緻密化できる.そのバルク材の内部組織は, 結晶粒 径が $0.3 \mu \mathrm{m}$ 程度の等軸状の $\alpha \mathrm{Fe}$ と $\theta$ からなる micro-duplex 組織となっている.

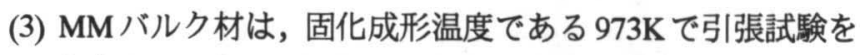
行うと, $10^{-2} \sim 10^{-1} / \mathrm{s}^{-1}$ の歪速度で $100 \%$ 程度の伸びを示す. この歪速度領域では, 0.3 程度の $\mathrm{m}$ 值が得られ, しかも破 断した試験片の粒内には転位はほとんど観察されず,また $\alpha \mathrm{Fe}$ 粒の大きさもほとんど変化していない.これらの事実 は, MM粉末の固化成形時の変形に, 粉末自体の微細粒超 塑性変形の機構が関与していることを示唆している.

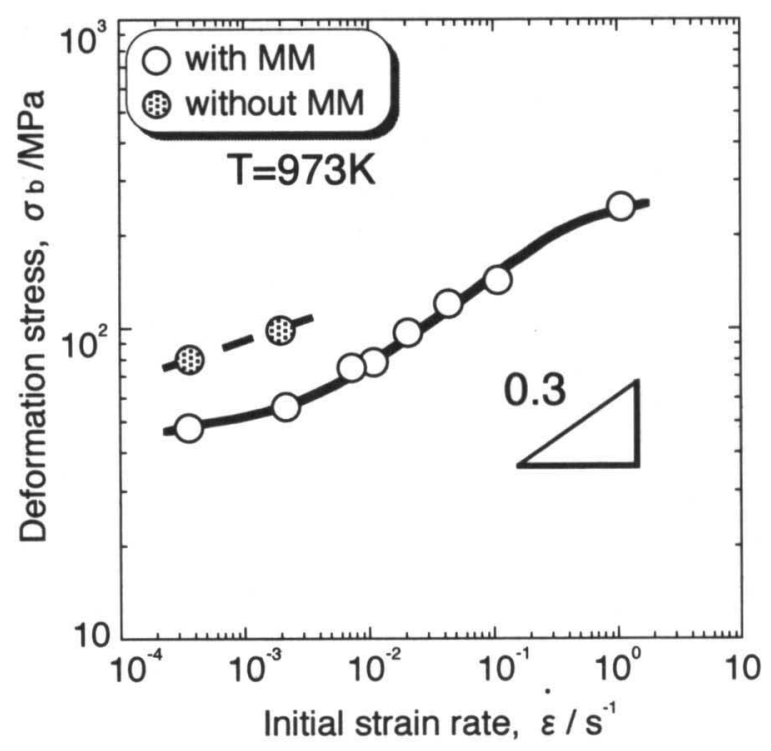

Fig.9 Relation between initial strain rate and deformation stress in Fe-0.8mass\%C bulk alloy.

\section{文献}

1) H.Hidaka, T.Suzaki, Y.Kimura and S.Takaki: "Grain Refining during Heavy Deformation in Fe-C Alloys with (Ferrite+ Cementite) Two-Phase Structure", Proceedings of the 2nd international Conference "Towards Innovation in Superplasticity", T.Sakuma, T.Aizawa, K.Higashi ed., Kobe, Trans Tech Publications Ltd., (1999)115-120.

2) 飛鷹秀幸, 木村勇次, 高木節雄: "超強加工による鋼の結晶 粒超微細化と...", 鉄と鋼, 85(1999)52-58.

3) Y.Kimura and S.Takaki: "Ultra Grain Refining of Iron by Mechanical Milling Process", Proceedings of the 1998 Powder Metallurgy World Congress and Exhibition, Granada Spain, European Powder Metallurgy Association, (1998)573-578.

4) O.A.Kaibyshev: Superplasticity of Alloys, Intermetallides, and Ceramics, Springer-Verlag, (1992)212.

5) A.K.Ghosh, D.-H.Bae and S.L.Semiatin: "Initiation and Early Stages of Cavity Growth during Superplastic and Hot Deformation", Proceedings of the 2nd international Conference "Towards Innovation in Superplasticity", T.Sakuma, T.Aizawa, K.Higashi ed., Kobe, Trans Tech Publications Ltd., (1999)609616.
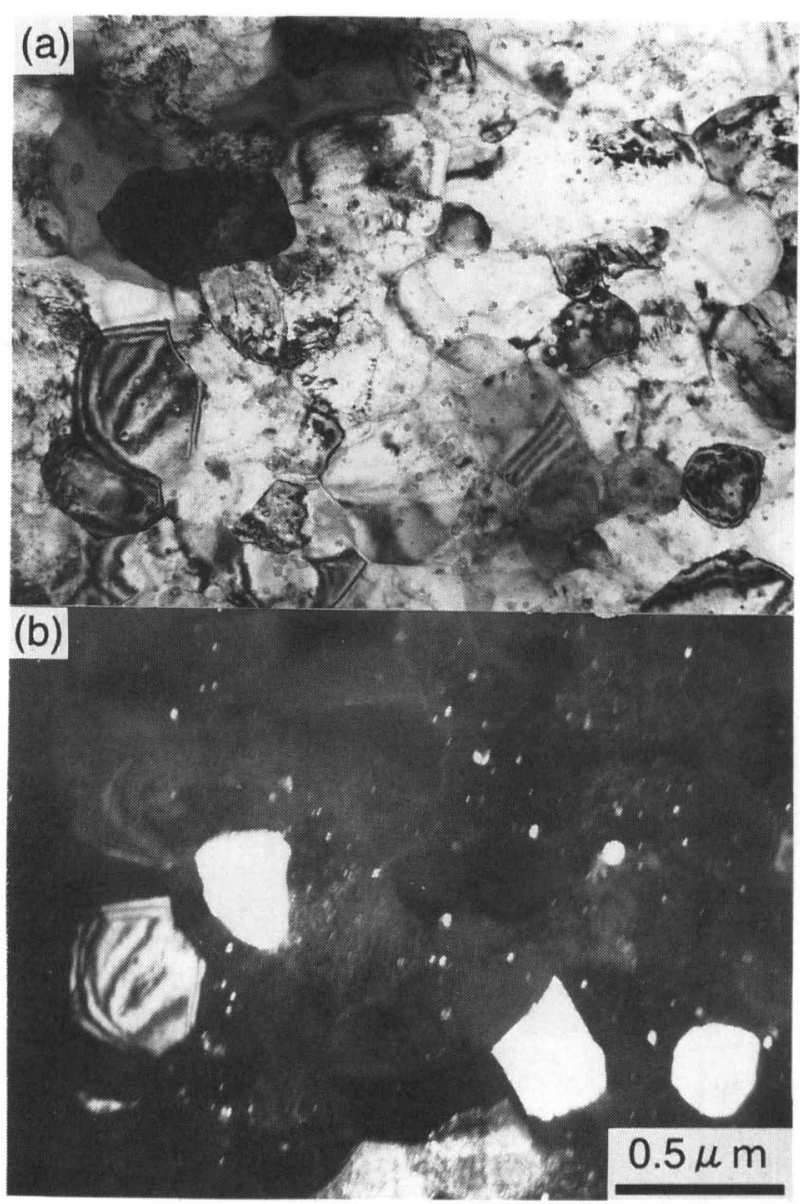

Fig.10 TEM images of Fe- 0.8 mass \% C bulk alloy near the fracture surface which was tensile tested at $10^{-2} / \mathrm{s}^{-1}$; (a) Bright-field and (b) dark-field. 